\title{
Natural Gas Virtual-Pipeline for Alternative Energy Distribution
}

\author{
Miguel Edgar Morales Udaeta, Jonathas Luiz de Oliveira Bernal, \\ Luiz Claudio Ribeiro Galvão and José Aquiles Baesso Grimoni
}

Additional information is available at the end of the chapter

http://dx.doi.org/10.5772/48711

\section{Introduction}

Virtual-pipeline is an alternative method of transporting natural gas to places where there are no pipeline networks available. It is based on a modular system of compression or liquefaction, transport and decompression and/or regasification of natural gas, which communities, industries, gas stations and others can use. In virtual-pipelines compressed/liquefied natural gas is transported by various modes - highway, railway, waterways and the sea.

For efficient use the end users -residential users, the gas stations, and industrial users should be located near the pipeline; otherwise, extension branches would be costprohibitive. Even users with high potential for consumption could not be using this fuel on account of their distance from existing pipelines. This was found to be a great problem by gas distributors. Trying to find a solution some companies have developed a new technological option: natural gas supplied through virtual-pipelines, which has the great merit of bringing the natural gas to regions not served by conventional pipelines.

The virtual-pipeline is a system that allows the natural gas transportation in the form of compressed/ liquefied gas using modules coupled to mobile platforms, which are transported by trucks, ferry boats, boats and/or rail platforms. When the product reaches its destination, the module is connected to a decompression/regasification station for ready consumption. The great advantage is that the amount of natural gas transported varies according to the needs previously determined by the customers. In short, versatile systems are supported by natural gas compression/liquifaction modules, regulation stations and the transportation system itself.

For each region a study is performed to determine particular dimensions, where the amount of gas to be consumed is previously determined, e.g., from probabilistic analyses of 
variables such as: consumption, distances, compliance with the transport, environment and security norms, climate condition, in addition to the technical and economic viability.

Thus, the Virtual-Pipelines and their specific features, such as type and storage capacity, means of transportation, compression and/or liquefying, loading, unloading and supplying, offer the remote customer the possibility of using the natural gas long before a conventional pipeline is constructed. This in turn contributes tremendously to the region's economic development.

In places where there is no natural gas, the industry is limited to work or develop products and services using the energy sources available in the region, and does not keep up with new technologies that can be more economical, with lesser emission levels and greater quality and reliability. The entrepreneurs can - having the possibility to use natural gas in the local market of any region, which is a cleaner energy source compared to the oil byproducts - develop more competitive goods and services in relation to internal and external competitors, thus stimulating their penetration into new markets.

The Virtual-Pipeline generates the flexibility for a more appropriate industrial location, and the possibility to have better utilization of geographical resources resulting in better cost/benefit relation. Natural gas facilitates the region to dispose goods that would not normally be developed in the region. This new technology also allows increasing number of GNV (vehicular natural gas) service stations, with a relatively smaller investment, emphasizing that this technology is also employed to other productive and service sectors, of which scattering demand disables the supplying through ducts (condos, commercial centers and small industries). This way, the users of vehicles provided with GNV have more flexibility to drive through the country side of the country, with natural gas available even in places where there are no conventional pipelines.

The utilization of the virtual-pipeline must not be treated as a steady and definite alternative, but as a faster way to take the natural gas to places where there is no technical or economical viability for the conventional pipeline. Virtual-Pipeline is a passport to new frontiers, consolidating the natural gas consumption and prepares the region for the future utilization of conventional gas supply. Given this case, the system of Virtual-Pipeline can be transferred to a new region that needs to be developed.

Due to increasing Green house gas concerns, the use of natural gas is encouraged. Additionally, with recent advances natural gas extraction from shale gas has become extremely popular. As sources of NG remain remote from locations of use viable technologies remain: Compressed Natural Gas (CNG), Liquefied Natural Gas (LNG), Gasto-Liquid (GTL) and Gas-to-Wire (GTW). These four technologies promote one way or another, the foundations of a virtual-pipeline. In this chapter, emphasis will be on the first two, and the third is a complementary one.

The last technology, GTW, is not discussed at length in this paper. The GTW technology consists of the production of electrical energy using turbines of open or combined cycles, close to the place of gas production, and the energy so produced is transmitted to the consumer market through transmission cables. 
The GTL (Gas-To-Liquids) technology on the other hand, comprises basically of conversion of natural gas into synthesis gas through a reformation reaction using steam (auto-thermal or partial oxidation) and subsequent conversion of the synthesis gas (syngas) into synthetic fuel through a Fischer-Tropsch reaction. The synthetic fuel so produced can be viewed as efficient use of natural gas itself, and further can displace oil consumption. Even considering the high costs for the construction of the plant, the value of the utilization of natural gas in the absence of pipeline network becomes attractive considering the low-cost of NG as compared to oil.

The benefit of synthetic fuel from GTL is somewhat similar to that from LNG. The LNG, through the cooling results in volume reduction for NG, facilitates its transportation by tank-ships, and subsequently, allows it to be regasified and distributed through pipelines to its final destination. The GTL, in comparison, transforms the NG into a synthetic fuel, which will be supplied as a liquid and used to fuel cars, buses and, possibly, jet engines. However, it is necessary to know that the capital investment for the construction and installation of a GTL plant are extremely high. It is estimated that U\$ 2,5 bi is necessary to generate only 100 thousand barrels per day; and the thermal efficiency of a GTL plant can only reach $60 \%$ (i.e., lots of energy is lost along the process before the fuel can reach the end user).

It is important to highlight that the largest consumer of natural gas in the world, the United States, by 2012, has reverted its position regarding the use of new technologies for unconventional NG and has started accelerated exploitation of shale gas. Also, it is said that the brute production of NG in the EEUU is the biggest one in all times, and it has reached 2.500 billion cubic feet on October 2011. It is further estimated that this value will keep growing, mainly due to the abundance of this unconventional gas (shale gas). And also due to the fact that in the case of the shale gas, the oil tanker knows exactly where the shale is the gas is derived economically.

This paper primarily discusses the natural gas virtual- pipeline as alternative to distribution of energy in the form of CNG and/or LNG. Additionally, though to a lesser extent, the production of synthetic liquid fuel is discussed as an alternative.

\section{Virtual-pipeline}

The concept of virtual-pipeline aims to distribute the natural gas to places where the physical or economic conditions deem the installation of a real pipeline unfeasible.

The so called Virtual-Pipeline consists of the transportation of the Compressed Natural Gas by pressure or liquefaction in the natural form at low temperatures. Once the mean or state of the natural gas is defined (compressed or liquid) for the achievement of the virtualpipeline, it will be transported into modular containers to the unloading plants. This allows the gas to reach the consumer centers in an economically feasible way, competitive or not, in general far removed from the physical pipeline network. It is important to highlight that the economic coefficient is relative, being necessary to consider several logistical factors, such as effective cost of the diesel transported to these remote places. 
Natural gas may be distributed in three forms: compressed natural gas - CNG (Natural Gas in its physical compressed state); liquefied natural gas - LNG (Natural Gas in its physical Liquefied state); and, the natural gas hydrates -GNH (Natural Gas in its physical "solid" state). Where the CNG is more commercial and known, it is normally used as direct fuel to internal combustion engines or for heating of processes in industries. The LNG is more expensive and multi-faceted technologically, it is also considered as a vector of distribution to great distances. LNG often proves economically feasible for maritime transportation to great distances. Although, the NGH, i.e., Natural Gas Hydrates, are technologically more complex, they are already past the testing phase, and a few plants are already under construction on industrial scale.

\subsection{Relevant aspects of the distribution via virtual-pipeline}

The virtual-pipeline, as already defined, can be identified as the natural gas distribution through containers, independently of the natural gas physical state. In the event of the virtual-pipeline the compressed state is the most dominant one, i.e., the CNG. In this sense, the CNG is the natural gas processed and conditioned for transport, commonly, e.g., into ampoules and cylinders, at environmental temperature, pressure 70 to 250 bar, with a volume reduction from 60 to 225 times the volume occupied under standard conditions.

The virtual-pipeline allows meeting the demand in regions where there is no infrastructure of gas pipelines distribution nets. It also aims to encourage the development of new markets for the natural gas, once it is highly flexible. It must be said that the transportation of CNG is complex and it involves risks of accidents due to the high pressure operation. Basically, the natural gas is taken out first, next the gas is compressed, and later the gas is transported to the purchasing point.

As time passed, the demand for gas has increased in all regions, however, its supply through conventional pipelines has not kept up with those needs. As a result a Compressed Natural Gas (CNG) system that can meet the cities' needs for electricity generators, automotive sector, industries, industrial utilization, etc., is very much the need of the hour.

In Russia, for instance, there are large swaths of populations that do not have access to the gas distribution network. As a result, they developed LNG (Liquefied Natural Gas) technology as an alternative transport which allows them to provide these places with natural gas by liquefying the gas, transporting it into trucks or vessels of convoy and subsequently regasifying it for its distribution, obtaining great results for system efficiency.

Nowadays there are enterprises working with the CNG or LNG technology. In South America, for instance, companies specialized at working with modular CNG achieve a distribution of more than 4,500,000 $\mathrm{m}^{3} /$ month to cities in Argentina. Such companies are intending to enter the Brazilian market together with local distributors in order to supply nearly $600,000 \mathrm{~m}^{3} /$ month of natural gas. 
There are other technological options available in the South American natural gas market as an alternative of transport: the cryogenic system. The gas is liquefied at $-162^{\circ} \mathrm{C}$ and stored into special tanks for its transportation to the consumer place. The cryogenic alternative of LNG is practical and great volumes of gas converted into liquid can be transported.

\section{Technological aspects of the virtual-pipeline}

During the technical execution of a virtual-pipeline, the CNG can be nominated gas into transitory state, due to the volume reduction and storage into pressure vessels. The supply of CNG in bulk consists of acquisition, receiving, compression, storage, delivery, commercialization and quality control.

The virtual-pipeline system is based on modular technology, which in turn allows scaling up of the system proportional to the demand. The Virtual-Pipeline described here (see fig. 1 ), is based on 3 technological developments, such as:

- Modular stations of CNG compression.

- Modular plants of pressure regulation.

- Modular system of Natural Gas storage and transport.
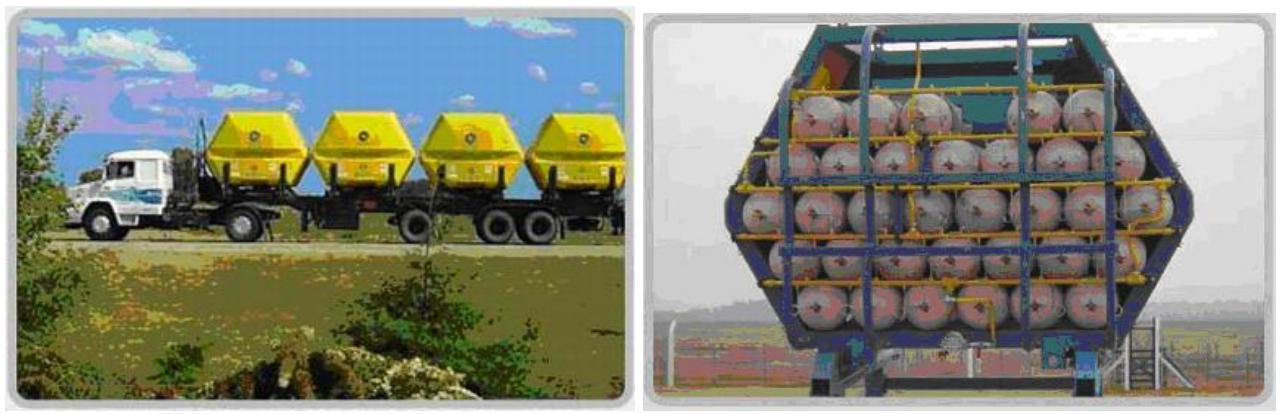

Figure 1. Technology developed in Argentina

First, a compressor is installed. Later, the CNG loading platforms are set at the place in a dispositive named STM - Storage and Transport Module - Tanks measuring $1500 \mathrm{~m}^{3} ; 2.2 \mathrm{~m} \mathrm{x}$ $3.6 \mathrm{~m} \times 2.6 \mathrm{~m}$. The STM are carried by trucks and transported by land to the unload platforms. Together with the unload platforms a controller plant which will reduce the outlet pressure (200 bar) to the pressure at the distribution net (4 bar).

In figure 2, the process of Loading of Galileo Technology is shown.

Following is the process of loading and unloading:

Head Station: A MICROBOX/MICROSKID (a complete and compact system of intrinsically safe compression), connected to a natural gas source, it can be an existing pipeline, compresses the gas within the STM modules of transport. These are on platforms, called PA$\mathrm{C}$, which allow the fulfillment and interchange between the module and the Transport System (step 1, see figure 3). 


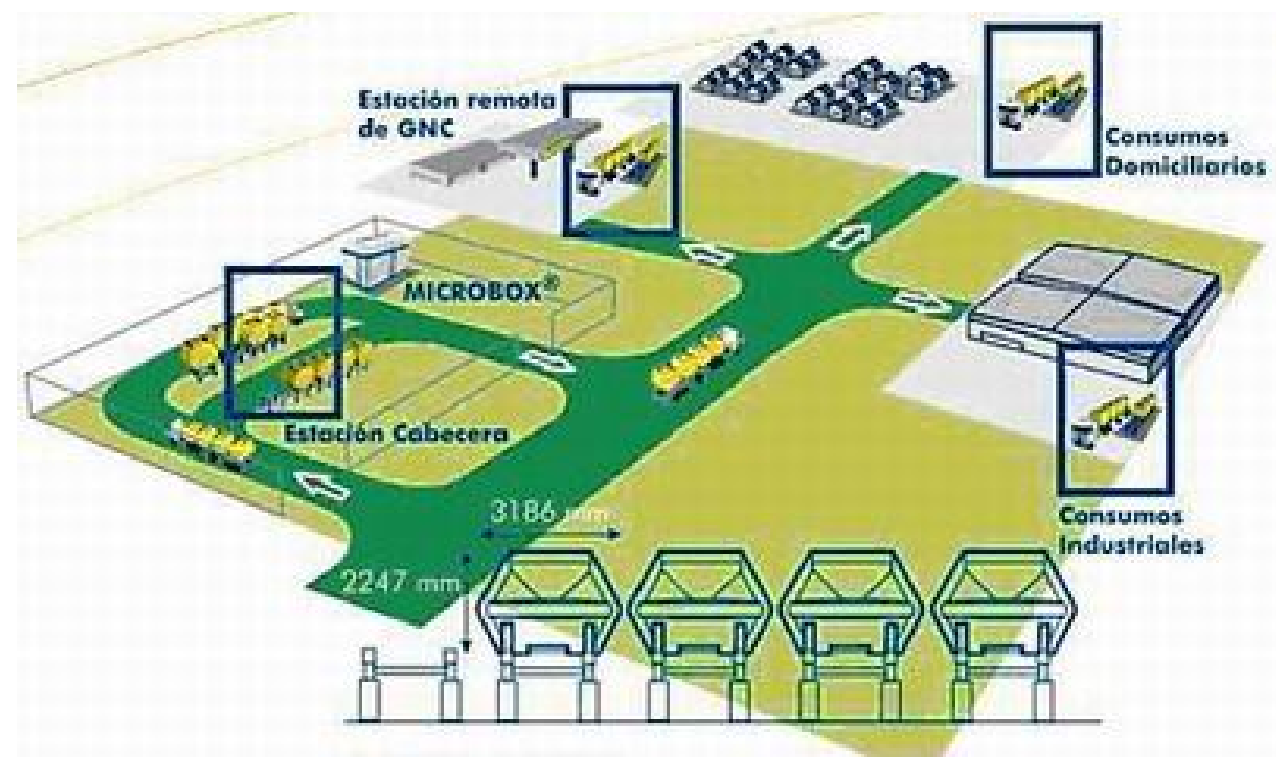

Figure 2. Loading System for the Galileo Technology in Argentina

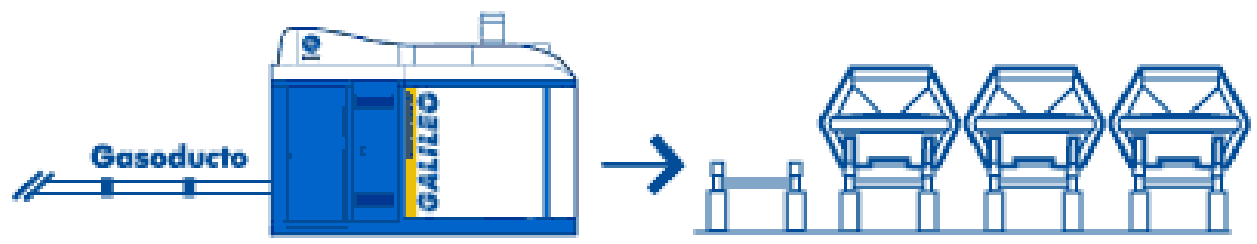

Figure 3. Step 1

Loading and Unloading: At its arrival, the transport trailer interchanges the empty STM from the consumer point by the filled ones. This interchange is executed by means of TS machines (CNG Transport System) that are on the trailer (step 2, see figure 4)

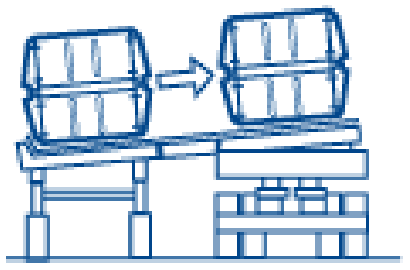

Figure 4. Step 2

Transportation: The vehicle transports the STM modules by land at the same speed as other loading transports, with no need for additional security system. The STM modules are linked to the trailer by an anchorage system. (step 3, see figure 5). 


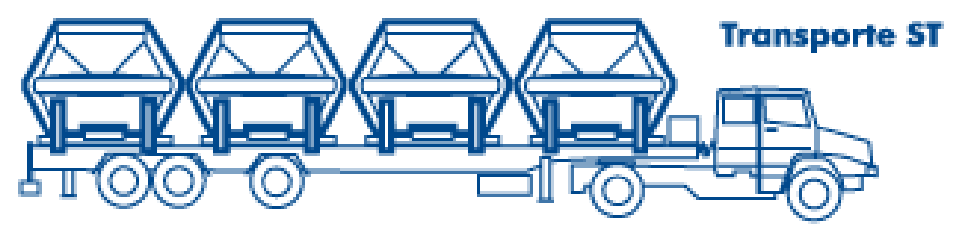

Figure 5. Step 3

When the consumer points are reached, the STM modules are unloaded on platforms, called PA-D (Plataforma de Abastecimento-Descarregamento) [SU-P Supplying - Unloading Platform]. In a previous step by a regulation plant, the STM are connected to the residential supplying net (step 4, see figure 6).

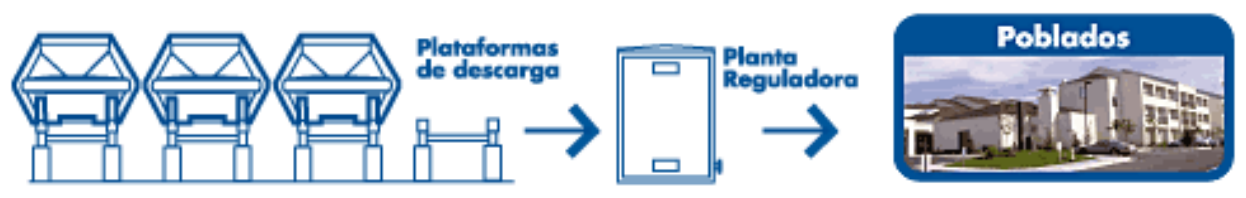

Figure 6. Step 4

At industrial applications, depending on the kind of industry, the platforms are connected to regulation plants. These have a catalytic heating system and the capacity to produce 10,000 m3/hour (step 5, industrial supplying, see figure 7).

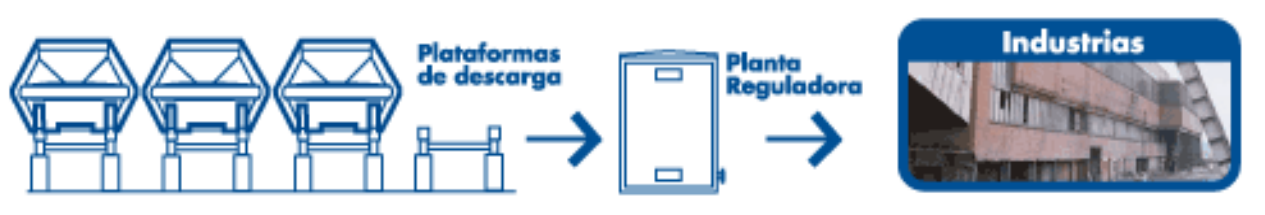

Figure 7. Step 5

Remote stations of CNG: The STM modules are connected to the filling station through an unload BOOSTER (small compressor and dispenser designated to recompression and supplying, respectively) and are managed by the Rotating Cascade (step 6, see figure 8).
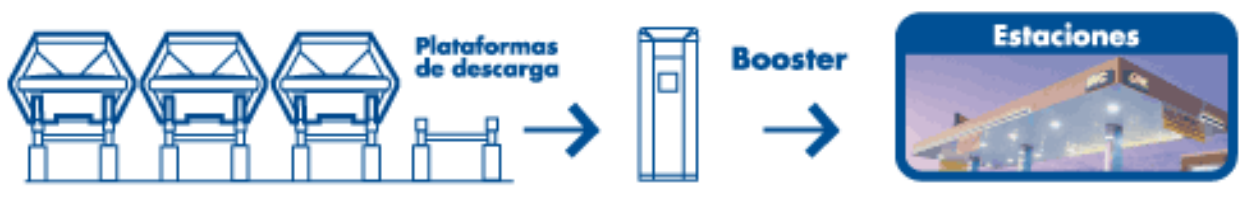

Figure 8. Step 6. 


\subsection{Cryogen technology}

This system consists of a gas caption station at a certain point, mechanisms for gas compression, injection into special tubes disposed on trucks, and decompression stations at the consumer end. The system developed by Cryogen makes it possible to use the dragging of the tubes as a supplying source for direct consumption, i.e., the supplying source in the industrial line.

To avoid the interruption of supplying the empty trailer is substituted by the filled one and taken to the caption point for its reloading. The most important limitation consists of the distance between the caption point and the consuming point. Longer distances with more than $200 \mathrm{~km}$ make the alternative difficult because of cost. Distances between 150 and 200 $\mathrm{km}$ are considered ideal.

The Cryogen system presents two alternatives for the utilization of CNG: the first one related to the trucks parked at the consumer point that decompress the gas with an independent energy equipment, using the environmental conditions to decompress; the second one uses compressor to keep the necessary pressure at the filling of the vehicular cylinders.

The first system - compression, transportation, decompression - for industrial consumption, includes the setting up of the compression system at 250 bar for the filling of the transport unit, the decompression system for industrial use between 2 and 30 bar. The standard Cryogen system consists of a transport system equipped with 150 cylinders of 125 liters capacity each, summing up $5.155 \mathrm{~m} 3$ of NG each journey.

The second system - compression, transportation, decompression, compression - is used directly for the automotive sector. This system is composed by a valve at the caption point, a compression system at 250 bar, filling mechanism, equipment for loading and unloading of cylinders and decompression and compression systems for the vehicular natural gas (VNG) supplying stations. Figure 8 shows the manner in which the modules of Criogen technology are adapted to the trucks used for transportation.

\section{Technological aspects of LNG}

The LNG (Liquefied Natural Gas) is liquefied by the reduction of its temperature to $-162{ }^{\circ} \mathrm{C}$ and regular atmospheric pressure and it occupies around 1/600 the volume of NG in gaseous state.

At first, the LNG relative to virtual-pipeline presents basic distribution conditions similar to the CNG, however, distances, volume and financial-economic analysis are different.

Technologically, in the case of its final use in transportation vehicles, the LNG is stored at low pressure into thermally isolated tanks and with capacities that can vary from 174 to 511 liters. The isolation of the reservoirs, even though very effective, cannot keep the temperature low. 
The LNG is stored as a cryogenic product, i.e., in liquid state at its evaporation temperature of $-162^{\circ} \mathrm{C}$. However, due to thermal losses into the storage tank, there is usually some boil off vapor that must be vented to maintain constant pressure.

The LNG is transported in towing trucks that carry more than 40 thousand liters, into small cistern and towing trucks, railway wagons and methane ships for LNG with capacity reaching 114 million liters. The towing trucks for LNG are often used to resupply the LNG stations, such as the delivery of gasoil or gasoline.

The system consists of deposits of LNG (liquefied natural gas) at the extremities of the "line", and a series of vehicles making the transportation of it. The same way as gasoline transportation is performed between the supplying stations.

Nevertheless, the components are a little more complex considering that the LNG must be kept at low temperatures in order to avoid its evaporation. The containers must have a double covering layer and be isolated by an insulating material developed by NASA, called super isolating "SI". Just one inch SI is more efficient than 30 inch sponge or glass fiber. Besides, the stationary containers have SI, isolating dust and "vacuum".

The transferring equipment between containers consists of a centrifugal pump that can be submersed or be apart between the terminals. Separated pumps usually need a long time of cooling to reach operable temperatures.

The transportation tanks are available in several sizes, normally projected to minimize the cost per weight, respecting the local laws of maximum weight and conditions of the highways. This means aluminum tanks with no transferring pumps. In the United States, for example, a vehicle used for the LNG transportation has its total capacity of $21,500 \mathrm{~kg}$. It is important to emphasize that this technology means great investment costs.

Small vehicles are used for remote areas, high pressures and pumps on board, e.g., in the United States special tanks are used to fuel 400 liters vehicles in 5 minutes or less.

There are also LNG wagons, but the supplying stations are limited to places with railway access.

In the event of the virtual-pipeline, now, the considerate and known technologies are those that allow the delivery of natural gas in both dominant physical states of the natural gas: liquefied and compressed. In this sense the supplying stations for both, LNG and LCNG where, certainly, the LCNG is the compressed natural gas (CNG) produced from the liquefied natural gas (LNG). For those regions distant from the transportation and distribution system of natural gas, the installation for this kind of stations is advantageous. The LNG, for example, can reach the supplying station by train or highway, in tank-trucks. Finally, the components of a station or substation of LNG and CNG (i.e., LNG and LCNG), are basically:

- Cryogenic system: it concerns a tank for LNG storage (normally, with a capacity between 50 to 100 thousand liters); 
- Transferring system: it is the tubage (it can be isolated by a vacuum system), the pump, the heating changer, the supplier and the control panel.

Thus, a LCNG station (GNLC in Portuguese), compared to the LNG station has one more pump, a vaporizer and a supplier. In the event of the cryogenic and compressed system, the LNG at cryogenic temperature $\left(-162^{\circ} \mathrm{C}\right)$ and low pressure is converted into $\mathrm{CNG}$, having more energy efficiency (less energy consumption) than the compression station. Although, the required power by the system pump/vaporizer is $1 / 10$ to $1 / 20$ of a traditional compression system.

It is interesting to mention that for determined transport vehicles, when the necessary autonomy is not reached with the CNG, the use of LNG has its advantages. That is why a LCNG station can fuel both LNG and CNG vehicles, as a conventional supplying station. The time of supplying with LNG is relatively equivalent to that of regular fuel. This is the reason why the fuel system, for a vehicle provided with LNG has such features: a reservoir; a vaporizer where the secondary fluid is the engine cooling liquid; an indicator of the level at the reservoir; and, to provide the engine with LNG at gaseous form.

\section{Synthetic fuel from natural gas}

During the World Wars, the natural resources became scarce, leading to a lack of liquid fuel and ammonia base required for explosive production. This resulted in a search for artificial processes to obtain from the well known synthesis gas (syngas), primarily derived from charcoal. More specifically, during the 1920 decade, in the last Century, the production of liquid hydrocarbons has been initiated from the synthesis gas using iron based catalysts developed by the scientists Franz Fischer and Hans Tropsch.

The Fischer-Tropsch method - FT converts the synthesis gas, compound by hydrogen and carbon monoxide into a wide range of hydrocarbons. The synthesis gas can be produced by a great variety of sources: from sources derived from oil, such as the natural gas, to sources as biomass or even residential organic garbage. Through the utilization of an Iron-Cobalt catalyst, combinations of these liquid hydrocarbons of great commercial use can be obtained, such as: diesel, naphtha, Dimethylether, methanol and others.

Some time ago, the investments in this technology did not stabilize due to the volatile cost of oil in the last years, causing a restriction in the supply for other priority markets of natural gas.

Another process to obtain liquid fuel from the gas is known as Davy Process Technology, that consists the production of a pumping product and sulphur-free from the natural gas. Because it is a compact technology, it is quite indicated for off shore installations of NG extraction.

\subsection{Diesel from natural gas}

The product of GTL is a liquid, somewhat similar to that of diesel, and further eliminates sulphur completely. As a result, GTL has the potential to serve as a replacement for diesel, and thereby can exploit an existing market. 
The use of GTL derived fuel worldwide, mainly in the developed countries, would help to improve the air quality in the cities due to the absence of sulphur. Still, concerning a much more articulated position, it can be used as precursor for efficient use of energy and reducing emissions, while meeting the fuel property requirements for the transport sector.

GTL diesel, in addition to not having sulphur, does not have long chain aromatic compounds. Features that turn this fuel into an ideal mixture for intermediary distillated market, very attractive to be used as product for fuel with very low emissions, having cleaner and ecological characteristics. Also, use of GTL derived diesel bolsters a country's energy security through diversification of fuel sources.

\subsection{Methanol from natural gas}

Also known as Methyl Alcohol, Wood Alcohol, Methyl Carbinol, Colonial Spirit, Wood Spirit, Methyl Hydroxyl, Methyl Hydrate $(\mathrm{CH} 3 \mathrm{OH})$, it is produced through a three step process:

- $\quad$ Syngas, or Synthesis Gas production

- Syngas conversion to brute methane

- Purification through distillation

There are six companies that own the patent over this process: Haldor Topsoe, M.W. Kellog, Lurgi, Mitsubishi Gas Chemicals, Synetix and Krupp Udhe. Synetix (ICI) that is majority in the market followed by Lurgi and Mitsubishi Gas Chemicals (AL-Shalchi, 2006).

In 1999 the global demand for methane was 27 million ton and in 2009 was almost 53 million of tons.

\subsection{Dimethyl ether}

Also known as dimethylic ether, methylethylic ether, methoxymethane or DME, it is the simplest of ethers presenting its chemical formula $(\mathrm{CH} 3 \mathrm{OCH} 3)$. Its physical-chemical properties are similar to butane and propane, facilitating both storage and handling.

The current production technology is the methane dehydration, with new ways of productive processes being developed, mainly used as an aerosol propellant.

\subsection{Other sub products from GTL}

The FT process produces a great range of hydrocarbons, from methane to molecules with more than 100 carbon atoms. In spite of commercial processes tries to break the great molecules in a search of bigger proportions of diesel aiming at greater market for its products, there is the possibility to produce the specialty products, such as:

- $\quad$ Linear normal paraffin (especially used in surfactants)

- Intermediate and combined paraffins (solvents)

- Wax 
Given the specialty products, such as the ones mentioned above offer attractive profit margins related to fuel products, the possibility of producing polymers from its base becomes uninteresting, as it would affect the price balance and the GTL conversion in large scale.

\section{Geo-energetic analysis for a virtual-pipeline in Bolivia}

The Bolivian Government has made it a national priority to provide all the regions in the country with natural gas and to change the energy matrix based on natural gas. The Hydrocarbons Ministry has been analyzing better natural gas supplying options to all regions, through both pipelines or virtual-pipelines. It is important to emphasize that in Bolivian territory there are large natural gas reserves, however the productive places currently find themselves geographically distant from the north of the country (Bolivian Amazonian region).

One of the greatest challenges to Bolivia is to change its energy matrix on the North of the country, which is geographically distant from the natural gas producing regions. The virtual-pipeline was evaluated to supply natural gas as an alternative to diesel that was used for power generation, and also to supply natural gas for other uses.

The incorporation of natural gas into the energy matrix of these regions would not only contribute to a cheaper energy supply, but it could also stimulate its use in the vehicular, commercial and residential sectors, improving life quality of its inhabitants and generating a cleaner local development.

It is observed then that there is a great need to supply natural gas to the North of the country. There is the VP (Virtual-Pipeline) technology to transport gas in an unconventional way, but an important aspect for the implementation of virtual pipeline is the analysis of access routes to the local consumer relevance, such as the cities of Guayaramerín and Riberalta. In both cases there is the issue of land access, which during the rainy season is practically impossible. Basically the 4 months, on average, the rainy season lasts, it is not possible to transport by truck, since the unpaved roads become impassable in the rain. The river is the only means of access, and therefore the virtual - pipeline implementation must be based in these areas after assessing the feasibility of transporting the gas in tanker-trucks from the river from Cochabamba to Guayaramerín. Geographically Cochabamba is at the center in Bolivia and Guayaramerím to the North right on the border with the Brazilian city of Guajará Mirim (see Figure 9).

\subsection{Bimodal corridor aiming at virtual-pipeline}

It all starts as the thesis of the use of the Bolivian territory to bi-oceanic interconnection (Pacific - Atlantic or vice versa). Such facility offers a range of alternatives to reach distant markets, primarily the United States and Asian countries. These alternatives are not competing with each other, but are complementary, tending to maximize the benefits. 


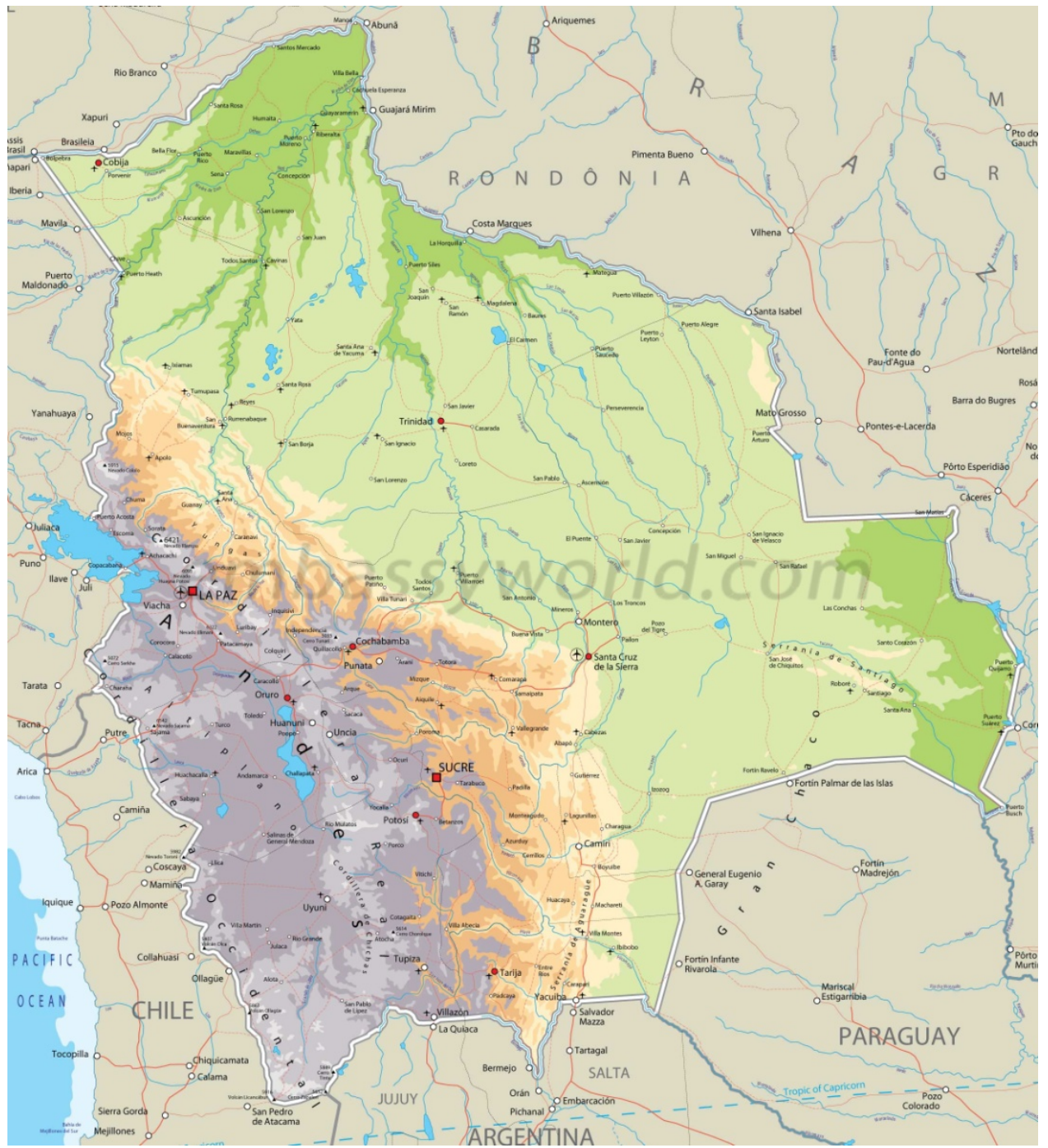

Figure 9. Bolivia Political Map

The alternative of an export corridor allows communicating with the Pacific Ocean, in the case of Brazil, the central area of Rondônia State, part of the State of Acre, and part of the State of Mato Grosso. In the central point and place of departure is the city of Porto Velho. The corridor would allow Bolivia to get to America on the Pacific coast(see figure 10). 


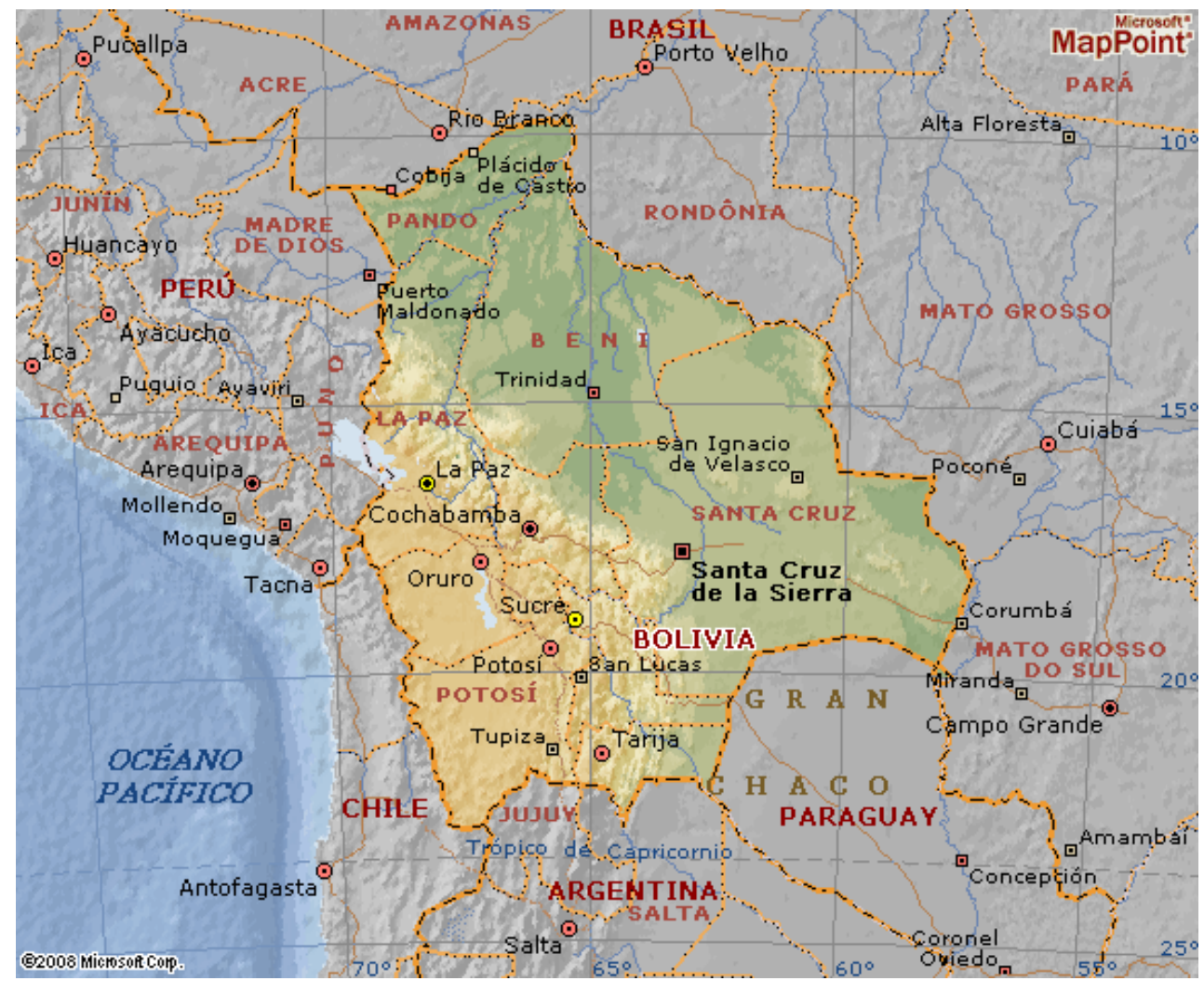

Figure 10. Geographical map of Bolivia from Pacific to Brasil

\subsection{Case study: Virtual pipeline in Bolivia}

In this item, it is not the intention to parse or analyze scientific basis of the VP (virtualpipeline), but search, in the context of scientific research in engineering, establishing pragmatic benchmarks of applicability in Bolivia for more remote regions such as north Bolivia (Amazon region shared with Brazil).

Bolivia has a physical environment varied (see Figure 11). It is located between the Andes and the Amazon Basin, with the altitude points around the 7,000 meters of sea level, for example, 6542 in the Nevado Sajama (the Andes) and negative altitudes in the Chaco region, but stand out formally 90 meters of sea level in the Rio Paraguay(Paraguay River).

Bolivia is then divided into three geographic regions: the Andean Region, formed by the Bolivian Altiplano and by the Andes, with altitudes of over 4000 meters, the Andean SubRegion, consisting of valleys and mountain rainforests of the Yungas, with a average altitude of 2000 meters of sea level., and the Plains Region, composed of subregions: Amazon, Platense and the Gran Chaco, with an average elevation of 400 meters of sea level. 
It is crossed from north to south by the Andes (Figure 11), divided into three systems: the Cordillera Occidental, the Cordillera Central and Cordillera Oriental. For this reason it can be deduced that the construction of pipelines across the Bolivian territory is little more than improbable, since they would cross, virgin forests, rivers, mountains and snowy areas. As a result one needs to consider other ways of supplying more remote regions of the capitals of each Department (equivalent to State in the Brazilian case).

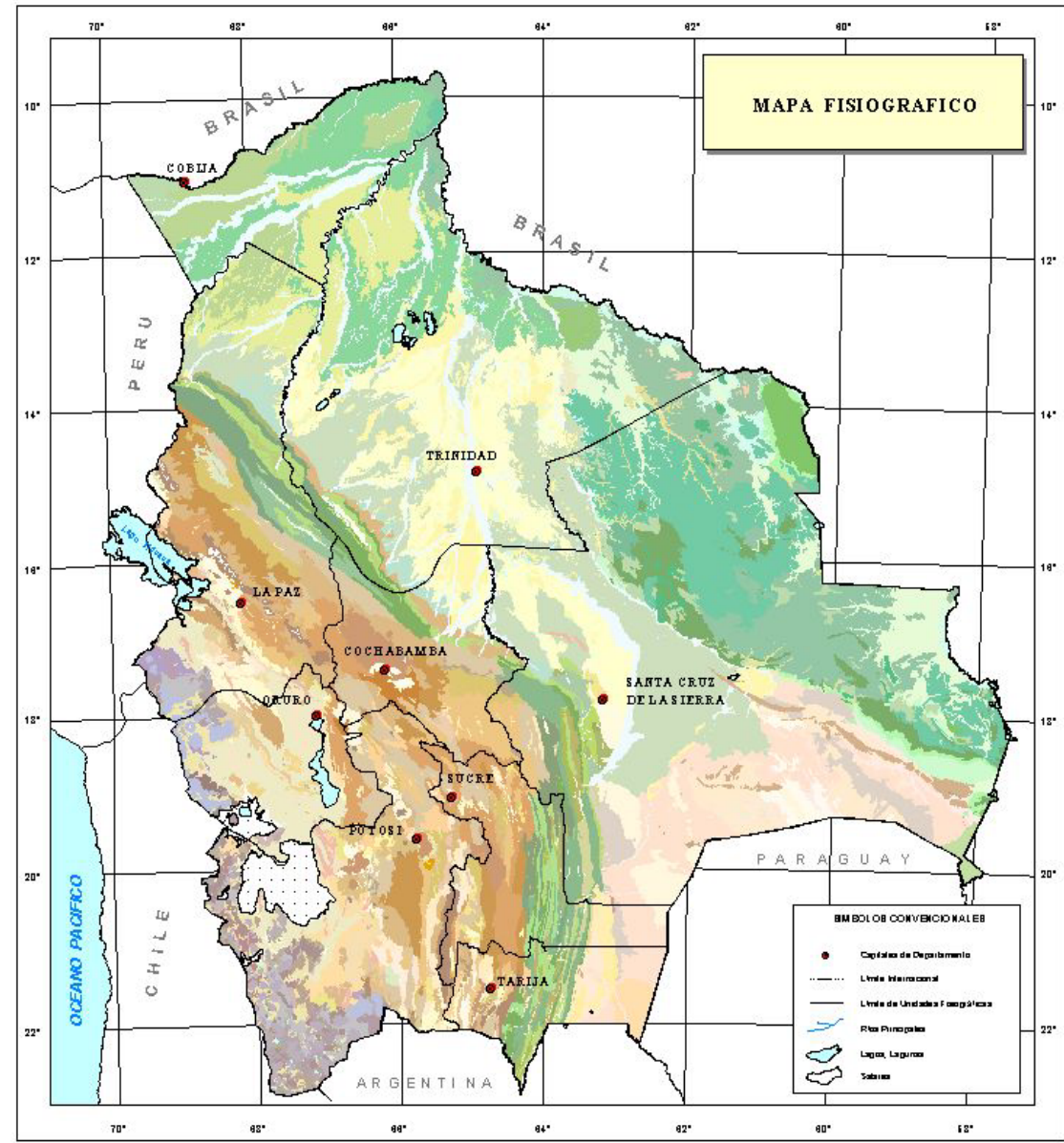

Figure 11. Topographic map of Bolivia.

An alternative to this problem is the so-called Virtual-Pipeline which consists in transporting the Compressed Natural Gas (CNG) under pressure or liquefied at low temperatures, transported in containers to the modular plant unloading, which will allow gas to reach the people away from the pipeline network cost-effectively. It must be emphasized here that the economics are relative, e.g., the effective cost of diesel transported to these remote sites. 
The construction of physical pipelines, particularly in complex terrain and urban areas can mean high investment costs, such as the Bolivian pipelines - Brazil, which required an investment of two billion dollars. The relatively high costs are compensated by higher volumes of gas transported through pipelines. In many cases the supply of natural gas to the pipeline in remote areas, and access costs are high compared to the volumes demanded. Under these conditions, the use of the VP (Virtual Pipeline) appears as a reasonable alternative to reduce the investment costs.

The choice between a physical and a virtual pipeline is a matter of capital costs, losses due to time spent, transportation distances, volumes of demand, etc. According to industry estimates, the economy of using the VP oscillates around $25 \%$ of costs. This percentage depends very much on the circumstances of each particular project.

The advantages of the virtual - pipeline where conventional systems for natural gas distribution are not economically viable or nonexistant, are clear because VP

- Allows supply of natural gas to all locations where the pipelines are not enough;

- Facilitates the "Flexibility" to enjoy the natural gas in its entirety - industrial use, commercial use and residential sector;

- Allows customers of the remote stations of CNG or LCNG to use natural gas up to 200 bar;

- Offers very low operating costs per $\mathrm{m}^{3}$ of gas transported, that are generally smaller than any other system.

\subsection{Analysis geo-energy for a virtual pipeline in Bolivia}

According to research conducted by NRECA (National Rural Electric Cooperative Association) and DAI (Development Alternatives, Inc.), we expect high demand for natural gas in the Chapare region, located in the Department of Cochabamba (Figure 12) in the short term. From information consolidated by 2006 , currently there are 2281 potential users in the residential category, 266 small businesses, large businesses 9, 6 small industries, two large industries and 600 vehicles wishing to be adapted to CNG.

Given the need mentioned above, the development of gas distribution in the Chapare (Department of Cochabamba as shown in Figure 12), it appears that from an investment of 3.8 million dollars there will be Compressed Natural Gas (CNG) for the benefit 21,000 inhabitants of the communities of Entre Rios, Ivirgarzama, Chimore, shinahota and Villa Tunari. The objective is to eliminate government subsidies for LPG and diesel, and establish a utility company with local participation in the Chapare.

But to change the energy matrix in the north, are being studied alternatives to the use of diesel for electricity generation by natural gas. The incorporation of natural gas in the energy matrix of these regions would not only contribute to providing a cheaper energy service, but can also, as already mentioned, its use to be driven sectors of small industry, rural, transport, commercial and residential use in the search for a universal, rational and reliable energy in Bolivia. 


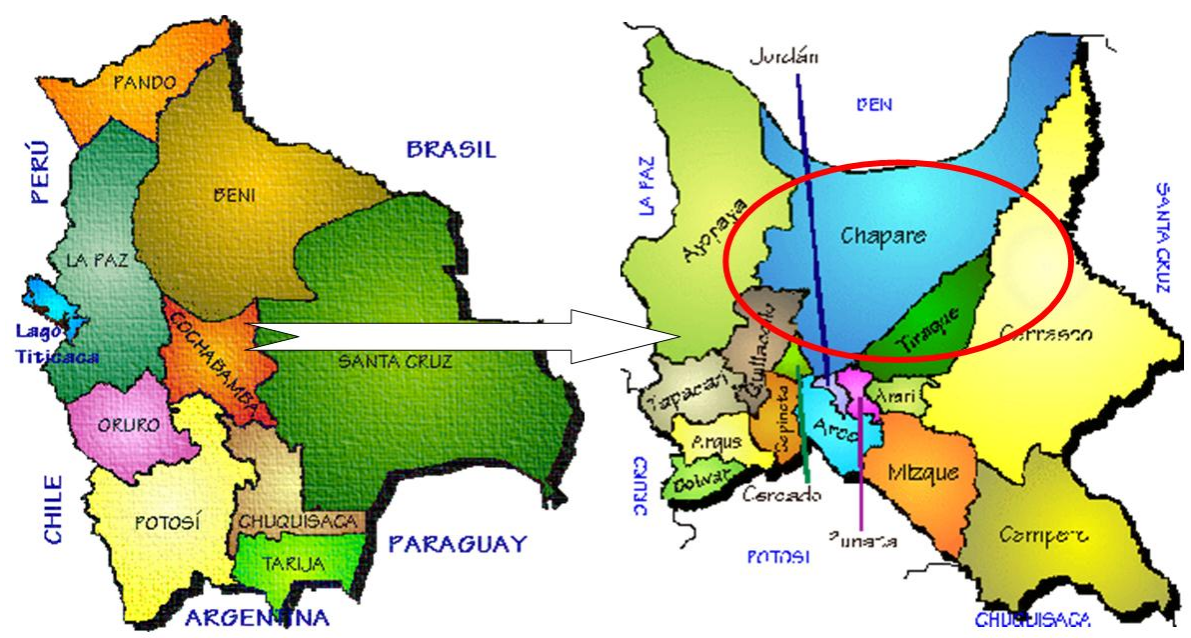

Figure 12. Location of Chapare in Cochabamba - Bolivia

The Departments of Beni and Pando (see Figures 10, 11 and 12) there are numerous power plants not integrated into the National Interconnected System (SIN). These plants use diesel for electricity generation, which absorbs much of the subsidy that the State grants to the fuel. According to Petrobras Bolivia in 2006 are required approximately 3,500 cubic meters of diesel fuel monthly to the departments of Beni and Pando.

The Government of the Beni Department is very interested in virtual pipeline project to supply the cities of Guayaramerín and Riberalta (see Figure 10), since the capital Trinidad is running the project interconnection Caranavi-Trinidad. It should be pointed out that the first two cities are the fastest-growing regions, besides the capital, Trinidad.

From the information posted above, it is observed that there is a great need to supply natural gas to the north. There is VP technology to transport the gas in an unconventional way, but an important aspect for the implementation of the VP (virtual-pipeline) is the analysis of access routes to the aforementioned locations Guayaramerín and Riberalta, within the Department of Beni. In both cases there is the issue of land access to rainy season it is practically impossible. For with the aforementioned, there are at least four months or more to the north of Bolivia (Amazon and countless rivers) is under heavy rains and it is not possible to transport by truck, since the unpavedroads become impassable in the rain. Thus, both pragmatically and in terms of sustainable river transport mode should be considered as a form of transportation, even as the river is the only means of access and in some cases throughout the year. These factors and others relating to modern development, should be considered as motivation to consider the pipeline as a tool for virtual supply. Still, the VP must support its implementation in these areas after assessing the feasibility of transporting the gas in tanker ships from the river up Guayaramerín Cochabamba (see Figure 13).

The route along the river faces the problem of navigation during the dry months, as the navigation is possible only between Trinidad and Guayaramerín, while in the rainy season is made from Puerto Villaroel (Cochabamba) to Guayaramerín. 
One of the most important aspects to define the viability of the virtual pipeline project in northern Bolivia is to analyze the possibility of making a navigable passage defined between the rivers Mamore and Ichilo called Ichilo-Mamore route (see Figure 14) during the whole year. In fact, this route when stabilized, would enable the virtual pipeline through a tank lighter, and can supply natural gas to all regions of the north. Moreover, to convert at once in a waterway that stretch between the 2 rivers, above, is a type targeted by soy producers in Brazil, since it would establish transport corridor between the bi-oceanic Atlantic and Pacific. Since bi-oceanic corridor that would allow an increase in the trade of soybeans, and, and also facilitate import/ export of all kinds of merchandise.

\subsubsection{Basics of bimodal corridor}

To demonstrate the viability of the virtual pipeline to northern Bolivia, aimed at diversifying the energy matrix and the massive use of natural gas thus reducing costs to the grant of traditional fuels. And also to consolidate and demonstrate that use of the waterway via the intermodal system reduces costs and facilitates a cleaner socioeconomic development. This item seeks to present some aspects of the bi-oceanic corridor. At the same time it demonstrates a synergistic way of harnessing a bimodal corridor (waterway and highway).

As already mentioned the basic reference is the proposal, based on comments by the Japanese of using the Bolivian territory to an interconnection between Pacific and Atlantic oceans or vice versa, which is called bi-oceanic. Thus the Brazilian soybean markets, for example, as China would be more than a thousand nautical miles closer. One is as easy to trade in goods of a high strategic value as it is soy, represents an opportunity to facilitate internal transport of goods in Bolivia, that opportunity may be entitled to the relevant secondary parents. One should also mention other distant markets, such as the United States for the pacific coast and other Asian countries. Since the alternatives do not compete with each other, are complementary, tending to maximize the benefits.

Accordingly, the basic aspects are identified (technical and economic) related to the bioceanic corridor, from studies of international research funds, the Department of Beni in Bolivia. These studies resulted in the so called "Study of the master plan for development of river transport in the Amazon region." Everything for the consolidation of the export corridor. The study allowed the definition of an alternative route for the implementation of the export corridor with an inter-modal transportation system that allows communication with the Pacific coast from the city of Porto Velho by land to the city of Guajará-Mirim in Brazil , passing through the waterway to Puerto Villarroel (starting at Guyaramirin through Tinidad) in Bolivia, and again by land to Arica in Chile. As shown in Figure 13.

The alternative export corridor allows communicating the central area of Rondônia State, the State of Acre, and the State of Mato Grosso. At the central point, and the place to start is the city of Porto Velho. The corridor would allow Bolivia to get to Arica (Chile) on the Pacific coast. A description of the distances, the state of the stretches of road and the travel corridor are shown in Table 1 and Figure 14. 

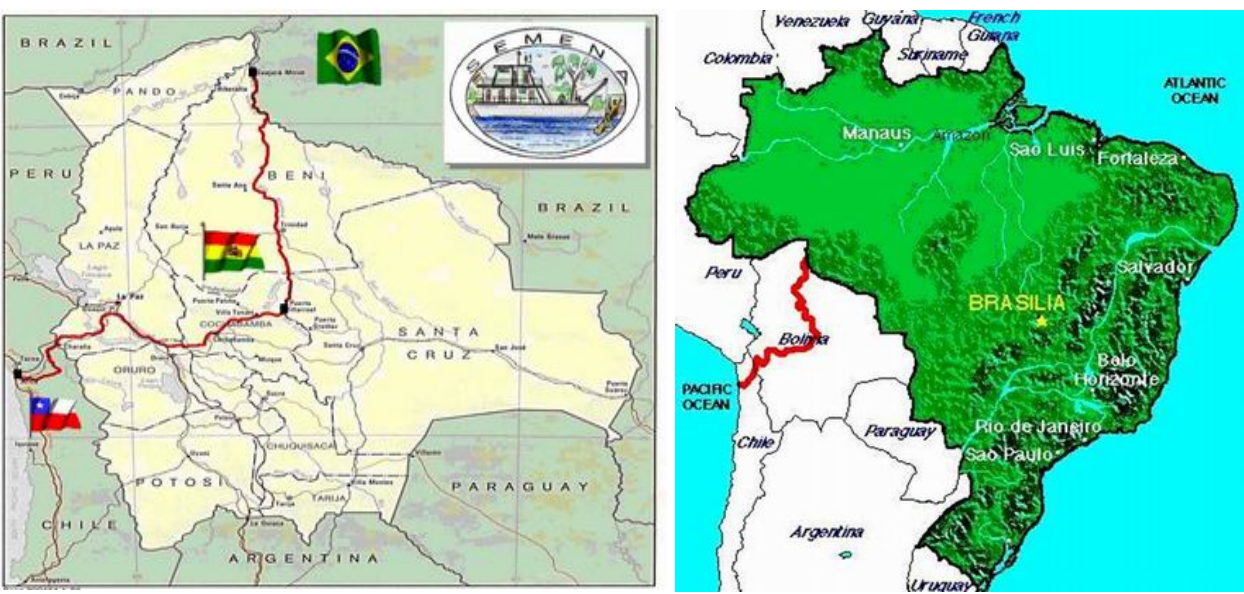

Figure 13. Bi-oceanic corridor

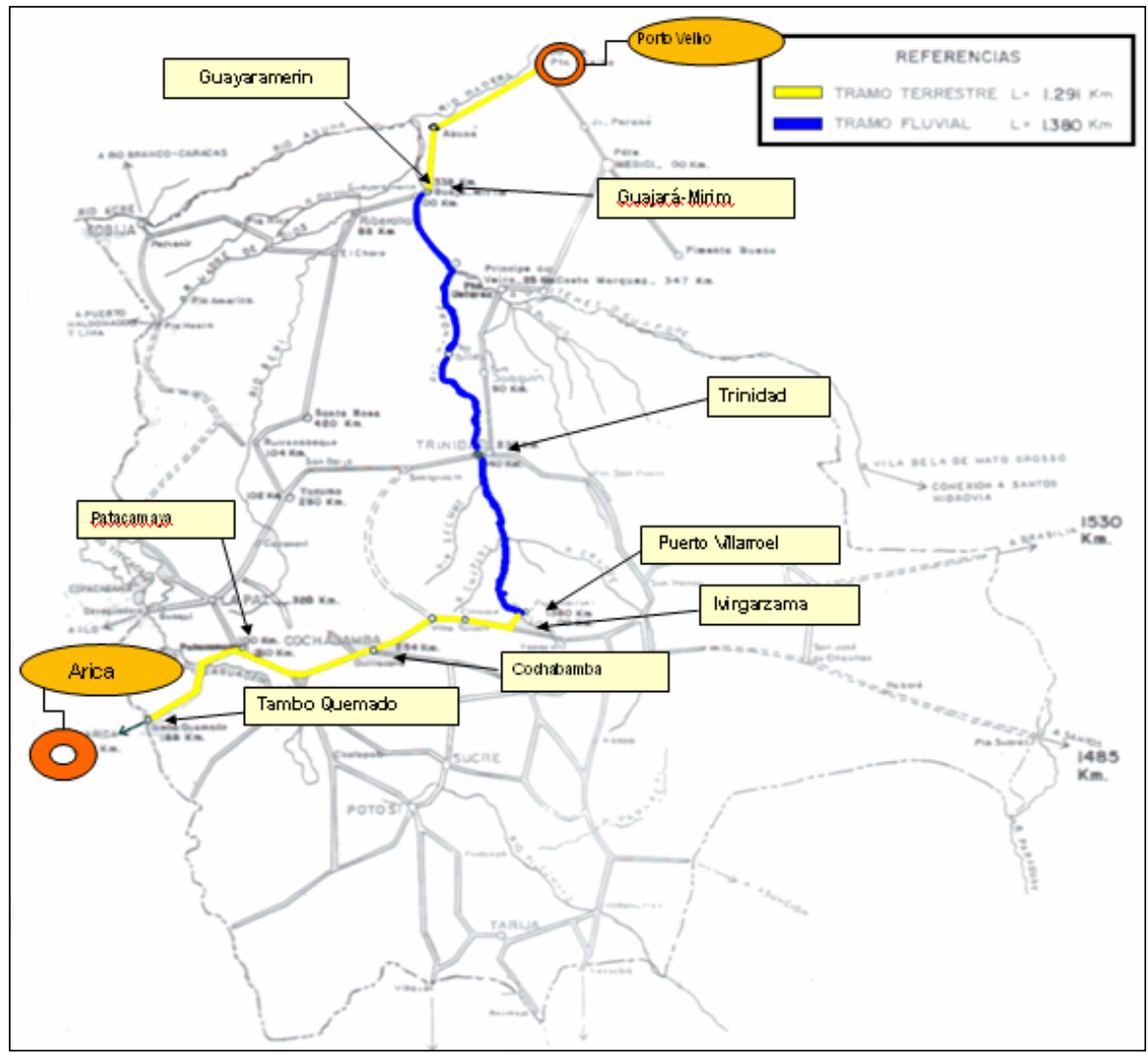

Figure 14. Bi-modal corridor design 


\begin{tabular}{|l|l|c|l}
\hline \multicolumn{4}{c}{ Bimodal Export Corridor } \\
\hline From & To & Distances (KM) & Situation \\
\hline Porto Velho & Guayaramerin & 338 & By land (pavement) \\
\hline Guayaramerin & Puerto Villarroel & 1.380 & By river (navigable) \\
\hline Puerto Villarroel & Ivirgarzama & 24 & By land (pavement) \\
\hline Ivirgarzama & Cochabamba & 230 & By land (pavement) \\
\hline Cochabamba & Patacamaya & 310 & By land (pavement) \\
\hline Patacamaya & Tambo Quemado & 188 & By land (pavement) \\
\hline Tambo Quemado & Arica & 201 & By land (pavement) \\
\hline & Total & $\mathbf{2 . 6 7 1}$ & \\
\hline
\end{tabular}

Table 1. Bimodal Corridor Distances

Currently there is infrastructure already existing to support this proposal. The bi-modal corridor would not have to start from scratch.

\section{Some aspects of the synthetic fuels NG}

Finally, GTL will be discussed mainly to show that it is an alternative to the virtual-pipeline which uses physical states (compressed and liquid) of natural gas to diversify this energy source. Natural gas also gains value through its chemical transformation, with the final product as synthetic fuels, of which the greatest interest is the synthetic diesel (clean diesel). GTL diesel also relies on the use of logistics and distribution system of traditional petroleum-based fuels for end use.

In this sense, the question to be examined a little more and it also refers to the industrialization of natural gas in Bolivia, and production of synthetic fuel (in the case of diesel it would be cleaner than regular diesel). This is the case of the GTL. The case of the GTL diesel has the advantage of the possibility of exporting synthetic diesel and would not have to import it. The GTL would generate productive jobs due to the secondary economy including other synthetic derivatives (already mentioned). Moreover, the use of GTL diesel would provide a cleaner environment in urban areas locally, and an overall effect in the case of greenhouse gases.

Energy resources play a key strategic role in the development of a country, primarily from its economic activity. The worldwide trend of increased energy demand, especially when it comes to a developing country, making the energy resources and energy demand, both in becoming a critical issue in terms of socioeconomic status. Ensuring supply and demand in balance in order to maintain rational over to fear an economic development, a sustainable environment and welfare of society as a whole is a constant challenge.

Therefore, it must be clear and it is interesting that the synthetic fuels produced from natural gas industrialization turn gains even when assessed in light of the virtual pipeline. Certainly it would be showing the actual multiple use of this resource, in this case, transforming it through the GTL process in synthetic derivates. From a technical standpoint, 
it is important to identify economic investments in technology and production costs for both projects, both GTL and VP or, in the sense competitive and / or synergistic effect of both. In commercial terms, the goal should be to identify current and future situations and VP GTL market and what it represents. From the viewpoint of economics, the intent is to determine relevant issues intrinsic to the GTL project and / or VP. Finally, but not least, legal and political questions relating to regulatory issues of conversions from natural gas, both chemical (GTL) and physical (VP), must be mastered, mainly relating to the site of end use.

\subsection{Prices of goods}

In the event that is being dealt here, i.e., a GTL project, the sales prices on the open market of derivatives stemming from natural gas, there is a significant degree of importance in order to be commercially viable. The real economic opportunities and financial feasibility of projects like GTL, in practice have always been influenced by the relative prices of natural gas.

In the specific case of Bolivia, even as this country has a current structure of state-controlled prices of natural gas in the mouth of the well has a forecast for the next year, from 4.0 to 5.0 U.S. \$ / MMBTU. Therefore, the GTL project in Bolivia would be limited to a large scale. It would also require the government to demonstrate the willingness in the item relating to taxes, even more so that companies have in the future natural gas reserves, have the power to make the decision to directly monetize its reserves, thus eliminating the need (determined by the current rules) that there is another company that operates a GTL plant.

However, the current state of affairs with respect to oil prices allows the development of type GTL ventures. This is because that when the value of a barrel of oil is over U.S. \$ 30 / Bbl, a GTL plant could reach an internal rate of return (IRR) of at least $15 \%$ for the worst case. Therefore, the GTL products (based on Fischer-Tropsch technology), due to its superior quality and could be sold at a competitive price compared to products from conventional oil refinery.

\subsection{Feasibility of GTL}

When it comes to evaluate the feasibility of an enterprise GTL it must necessarily be applied the 1:10 rule, this means that 2 TPC (trillion cubic feet) of natural gas reserves, should produce during 20 years, $20000 \mathrm{BBL} / \mathrm{d}$ of synthetic diesel on average (ultra-clean fuel).

In the Bolivian case, it is initially planned to produce 15,000 BBL / $\mathrm{d}$ between the third and fifth years, and so on increasing to maximum capacity. Thus, the operation of the GTL plant to reach full capacity in the seventh or eighth year. Verified bibliographic information consulted, units, such as those considered for the Bolivian case, range in capacities from $10,000 \mathrm{BBL} /$ day to $160,000 \mathrm{bbl} /$ day.

Moreover, according to feasibility studies, investment depends on the size of the plant. Where also it must be taken into account that such endeavors have returns every time the price of a barrel of oil is above thirty dollars. From the standpoint of investment, production of synthesis gas (commonly known as syngas), a key component in the GTL process 
corresponds to about $50 \%$ of the plant cost, when the separator unit including air. Since the synthesis of the Fischer-Tropsch (FT) requires about 15\% of the costs. However, the step of improving the product requires $10 \%$ of the capital investment. Since about $25 \%$ remaining is for the additional systems such as power generation and infrastructure.

For this reason and to define the feasibility of implementation and the size of a GTL plant, it is necessary to take into account various aspects such as supply and demand for FT products worldwide, demand for the domestic market of fuels, the availability of proven reserves of natural gas, costs of investment and technological trends. All this highlights the fact that when it comes to the physical layout of the plant is rather complex.

\section{Author details}

Miguel Edgar Morales Udaeta*, Jonathas Luiz de Oliveira Bernal, Luiz Claudio Ribeiro Galvão and José Aquiles Baesso Grimoni USP, GEPEA/EPUSP (Grupo de Energia do Departamento de Engenharia de Energia e Automação Elétricas da Escola Politécnica da Universidade de São Paulo), São Paulo, SP, Brasil

\section{Acknowledgement}

The authors thank FAPESP - São Paulo Research Foundation, because this work is the result and was developed based on the research support received from FAPESP, through research projects: FAPESP 2005/03059-0 “Modeling the Procedure for Systemic, Viable and Sustainable Use of Natural Gas in Bolivia Including the Development in Brazil", and FAPESP 2009/03168-4 "Background and Introduction To Supply Chain of Natural Gas".

\section{References}

Anuario Estadístico, Ministerio de Servicios y Obras Públicas, Viceministerio de Electricidad, Energías Alternativas y Telecomunicaciones, 2004.

Associação Portuguesa do Veículo a Gás Natural. Introdução ao GNL-GNC, $<$ http://www.apvgn.pt>. Lisboa, APVGN, 04. nov. 2007.

California Energy Commission, April, 2010.

Carrera G. A. Zamalloa “Avaliação de Alternativas Tecnológicas (GNL e GTL) para a Viabilização de Jazidas de Gás Natural Remotas em Países em Desenvolvimento" Estudo de Caso: Jazida de Camisea no Peru" 2004.

Carroll, J. Natural Gas Hydrates: A Guide For Engineers. Elsevier Science, ISBN: 9780080570020. eBook, 2009.

Centro de Documentação e Informação de Bolívia, 2006; www.cedib.org, 04/2006.

Centro de Tecnologia do Gas. Gás Natural, <http://www.ctgas.com.br>. Rio Grande do Norte, CTGas, 24 out. 2007.

Código Petroleiro Davenport de 1995-2000.

${ }^{*}$ Corresponding Author 
Department of Energy - National Energy Technology Laboratory. Energy, $<$ http://wwwe.doe.gov>. Washington, DC. DOE, 21 set. 2006.

Doria, M.S., 2003. “Gas Bolivia”; La Paz - Bolivia.

Duke Energy Gas Transmission Canadá. Natural Gas, <http://www.duke-energy.com>. Canadá. 04 nov. 2007.

Enbridge. The Northern Pipeline Story, <http://www.enbridge.com>. Ontario, 12 jul. 2002.

Energy Information Administration. International Energy Annual - Natural Gas Tables, <http://www.eia.doe.gov>. Washington, DC. EIA, 25 set. 2006.

Energy Press-Bolivia, www.energypress.com/Bolivia, 03/2006.

Foster Wheeler, Gas to Market Technology, 2002.

Galileo, S.A. website in order to inform, educate and communicate. www.galileoar.com; Buenos Aires - Argentina. 2012.

Galvão, L.C.R.; Udaeta, M.E.M. "Aspectos Relevantes do Gás Natural Visando o Planejamento Energético". In: III CBPE, São Paulo -SP. Junho de 1998. SBPE, Anais.

Geology College, November, 2009.

Grimoni, J.A.B. Galvão, L.C.R., Udaeta, M.E.M. Iniciação a Conceitos de Sistemas Energéticos para o Desenvolvimento Limpo. São Paulo, Edusp, 2004.

Institute of Americas, El Gasoducto Sudamericano "Mesa Redonda Ejecutiva Sobre La Integración Regional Energética". Presentada por: Ministerio de Industria, Energía y Minería del Uruguay y el Instituto de las Américas. Montevideo, Uruguay, August of 2005.

Instituto Nacional de Estatísticas de Bolívia; www.ine.gov.bo, 02/2006.

International Association For Natural Gas Vehicles. Natural Gas Vehicles, <http://www.iangv.org/>. Auckland New Zealand, IANGV, 12 ago. 2007.

International Forum: “Industrialización Del Gás Boliviano: Sueño o Realidad?" La Paz, December, 2003.

Kinn, L.C., 2004. "Política Energética Integral"; Santa Cruz - Bolivia.

Mde - Ministerio de Desarrollo Económico, Comisión Política de Estado sobre el Gas Natural, 2002. "Política de Estado sobre la Utilización del Gas Natural"; Bolivia.

Naturalgas. Natural Gas, <http://www.naturalgas.org>. Washington, DC, 28 out. 2007.

Oliva, R.C.R., "Exeqüibilidade da industrialização do gás natural na Bolívia e a sustentabilidade de abastecimento a mercados além das suas fronteiras", São Paulo Brasil, 2006.

Petrobrás. Programas Tecnológicos, <http://www.petrobras.com.br>. Rio de Janeiro, 04 nov. 2007.

Semena, Estudio de Factibilidad Socioeconómica, Financiera e Impacto Ambiental del Corredor de Exportación Porto Velho - Guayaramerin - Trinidad - Puerto Villarroel Arica o Iquique o Matarile o Ilo, 2006.

The Center for LNG. LNG Research, <http://www.lngfacts.org>. Washington, DC. CLNG, 28 out.2007.

Udaeta, M. E. M. et al. Pesquisa Tendências Tecnológicas do Setor Petróleo e Gás. Programa de Recursos Humanos para o Setor de Petróleo e Gás. São Paulo, Instituto de Eletrotécnica e Energia da Universidade de São Paulo. São Paulo, IEE, 2004 
Udaeta, M.E.M. Modelamento do procedimento para o uso sistêmico, sustentável e viável do gás natural na Bolívia incluindo o aproveitamento no Brasil. FAPESP, IEE/USP, GEPEA/EPUSP, CESU/UMSS. São Paulo - Brasil. 2007.

Udaeta, M.E.M.; Galvão, L.C.R.; Lafuente, R.J.O. Capitulo Bolivia. In: PAULA, Ericson de. (Org.). Energía para el Desarrollo de América del Sur. Mackenzie. São Paulo, 2002, p. 69-110.

Udaeta, M.E.M.; Grimoni, J.A.B.; Burani, G.F.; Rigolin, P.H.C.; Massara, V.N. Fundamentos e Introdução à Cadeia Produtiva do Gás Natural. São Paulo - Brasil, Edusp, 2010

Udaeta, M.E.M.; Lafuente, R.J.O. "Perspectiva del rubro energético en Bolivia y gas natural”. Cochabamba - Bolivia. Acta Nova Revista Semestral de ciencias y tecnología de la UCB. Vol. 2 № 2, Junho de 2003, p. . ISSN - 1683 - 0768.

Udaeta, M.E.M.; Zurita, R.O.R.; Lafuente, R.J.O.; Galvão, L.C.R. “La Industria Energética en Bolivia y su Vocación Integradora Através del Gas Natural" In. IV Encontro Brasileiro dos Profissionais do Gás, São Paulo, Gasbrasil, 2003, CD-ROM, Anais.

Udaeta, M.E.M; Reis, L.B; Lafuente, R.J.O; Zurita, R.O.R; Burani, G.F. "Análisis de Ia Industria Energética en Bolivia en el Marco del Mercado Competitivo". Rio de Janeiro Brasil. Periódico "Revista Brasileira de Energia" -Vol. 8 No 1- 2001, SBPE. ISSN OlO4303X.

Vega, F.F. de.; "El Gas Natural en América Latina y el Caribe”. Buenos Aires - Argentina, 2004. PennWell. American Petroleum Institute. Programs and Services, $<$ http://www.api.org>. Washington, DC, API, 04 nov. 2007. Gasvirtual. Informe, $<$ http://www.gasvirtual.com.br>. Rio de Janeiro, 05 nov. 2007.

Villanueva, Luz Z. D. Uso de Gás Natural em Veículos Leves e Mecanismo de Desenvolvimento Limpo no Contexto Brasileiro. São Paulo, Tese de Doutorado do Programa Interunidades de Pós-Graduação em Energia da Universidade de São Paulo, 2002.

Yacimientos Petrolíferos Fiscales Bolivianos; www.ypfb.gov.bo, 01/2006. 